\title{
Design Approach for Solar Photovoltaic Groundwater Pumping System for Eastern India
}

\author{
ATIQUR RAHMAN ${ }^{\star 1}$ and B.P. BHATT ${ }^{1}$ \\ 'ICAR Research Complex for Eastern Region, PO: Bihar Veterinary College Campus, \\ Patna-800 014, Bihar, India.
}

http://dx.doi.org/10.12944/CWE.9.2.25

(Received: March 20, 2014; Accepted: April 27, 2014)

\begin{abstract}
Eastern India has rich resource base for intensive and diversified agriculture, but the production and productivity of this region is quite low due to lack of assured irrigation as even a short dry spell of drought adversely affects the stability of agricultural production. The energy squeeze in terms of lack of grid electricity and substantial increase in diesel prices refrain farmers from operating pumps for required number hours to fulfil their irrigation needs. Eastern India possesses enormous solar energy potential with solar radiation of $4.0-6.4 \mathrm{kWh} / \mathrm{m}^{2} /$ day and $250-300$ bright sunshine days/year. Therefore, it can be a year round reliable source of energy for groundwater pumping to meet supplementary irrigation requirements. In addition to energy reliability, the environmental pollution in terms of carbon emission could also be reduced. However, in view of initial investment cost of solar pumping system, cropping patterns and landholding sizes, the solar photovoltaic pumping system should be of appropriate size and should be designed in view of solar radiation availability, groundwater depth below ground level and crop water requirement in different seasons. This paper discusses about the design aspects of solar groundwater pumping system to fulfil these propositions.
\end{abstract}

Key words: Solar energy, Irrigation, Irradiance, Groundwater.

\section{INTRODUCTION}

In Eastern India most of the land holdings are of small category and food production systems are often been risky and relatively of low return due to erratic rainfall. This is expected to worsen in coming decades under the climate change ${ }^{1-2}$. The smallholders of this region could play an increasingly important role in food production if they had timely access of irrigation water ${ }^{3}$. The assured irrigation could be providing ample opportunities to the farmers to invest in high yielding seeds, growing high value crops with crop diversification; as promotion of irrigation itself is a strategy for poverty reduction, climate adaptation and food security ${ }^{4-5}$. The average solar radiation incident over the landscape of Eastern India varies between $4.0-6.4 \mathrm{kWh} / \mathrm{m}^{2} /$ day with 250 -300 clear sunshine days in a year-7. Therefore, the promotion of solar energy particularly in groundwater pumping is indeed required in view of current energy deficit and high growth rate of energy consumption in agriculture ${ }^{8}$. In addition to this, the use of modern irrigation technologies could reduce the overexploitation of groundwater and environmental degradation $^{9-10}$.

\section{System Configuration, Sizing of Pump and Solar Array}

In solar photovoltaic groundwater pumping system the main components are the solar array, power conditioning unit and sun tracking mechanism. If water source is a deep well then submersible pumps are preferred. However, if water source is a shallow well then surface pumps can be a better option. Though, in solar photovoltaic ground water pumping DC pumps are preferred, however, the AC pumps can also be operated by solar energy by using a VFD (Variable Frequency Drives). So for only 
limited capacity DC submersible pumps are available in the market and therefore if higher capacity pumps are required then user has to opt for AC pumps. In solar photovoltaic pumping system, commonly two types of system configurations are prevalent. In first configuration, a submersible pump lifts groundwater into an overhead tank which serves as an energy store and supplies the pressure needed for the pressurised irrigation system. In second configuration no storage system is used and water is directly injected into the irrigation network. Another configuration, developed by authors is shown in Figure 1. In this configuration a submersible pump lifts water into a grounded tank which serves as water reservoir for fish and duck farming. An additional DC centrifugal pump delivers water from the tank to the fields for irrigating crop either by surface method of irrigation or by pressurized method of irrigation by feeding water directly to the irrigation network. The advantage of this configuration is lies in the fact that the water can be delivered to distant fields at relatively high pressure without any increase in dynamic head of submersible pump. Under this configuration, more groundwater can be drafted per day and daily more cropped area can be irrigation.

Since, water required to irrigate a cropped area depends upon the number of factors such as types of crop, crop growth cycle, type and condition of soil, land topography, application efficiency etc. This requires quantification of groundwater availability on daily basis as well as season wise. Further, the daily extracted volume of groundwater depends upon the

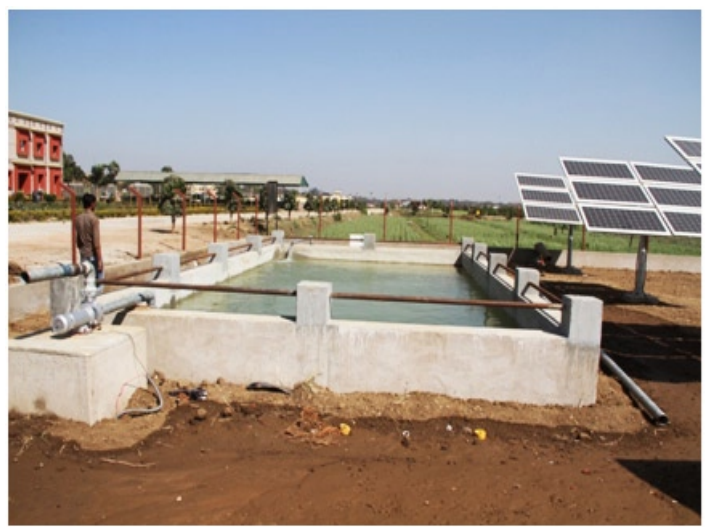

Fig. 1: The schematic of solar photovoltaic ground water pumping system capacity of the pump, pumping depth and duration of operation. Mathematically, for given water volume, the requirement of energy and pumping depth can be connected as

$\mathrm{E}=\rho \mathrm{gVd}$

where,

$E=$ Hydraulic energy in joules $(\mathrm{J})$

$\mathrm{V}=$ Required volume of water in $\left(\mathrm{m}^{3}\right)$

$\mathrm{d}=$ Head of water $(\mathrm{m})$ and

$\rho=$ Density of water (1 million gram per cubic meter or $1000 \mathrm{~kg}$ per cubic meter) then:

$$
\begin{aligned}
\mathrm{E} & =\frac{9.81 \times \mathrm{V} \times \mathrm{d}}{1000} \times 1000000, \text { Joules } \\
\text { or } \quad \mathrm{E} & =\frac{9.8 \times \mathrm{V} \times \mathrm{d}}{1000}, \text { Mega Joules }
\end{aligned}
$$

Thus, to lift $150 \mathrm{~m}^{3}$ of water from a depth of $20 \mathrm{~m}$ and if pipe head loss is supposed to be10 percent of the total head, then the required hydraulic energy is:

$$
9.81 \times 150 \times 22 / 1000=30.29 \mathrm{MJ}=8.41 \mathrm{kWh}
$$

If pump is to be operated for number of hours equal to the number of peak sunshine hours (say 6 hours), then the flow rate $(Q)$ in liters per second (Ips) is:

$$
Q=150 \times 1000 / 6 \times 3600=6.95 \mathrm{lps}
$$

The hydraulic power $(P)$, required to lift a given quantity of water depends on the length of time, the pump requires. As power is defined as the rate of doing work or the expending energy, therefore, the formula for hydraulic power could be obtained from energy formula by replacing volume with rate of water flow, i.e.,

$$
P=\rho g Q d \text { watt }
$$

or

$$
P=9.81 Q d=9.81 \times 6.95 \times 22=\cong 1500 \mathrm{~W}
$$

If $\eta$ is the efficiency of the pump, then

$$
\text { Motor power }=\mathrm{P} / \eta
$$

With a typical pump efficiency of $70 \%$, 


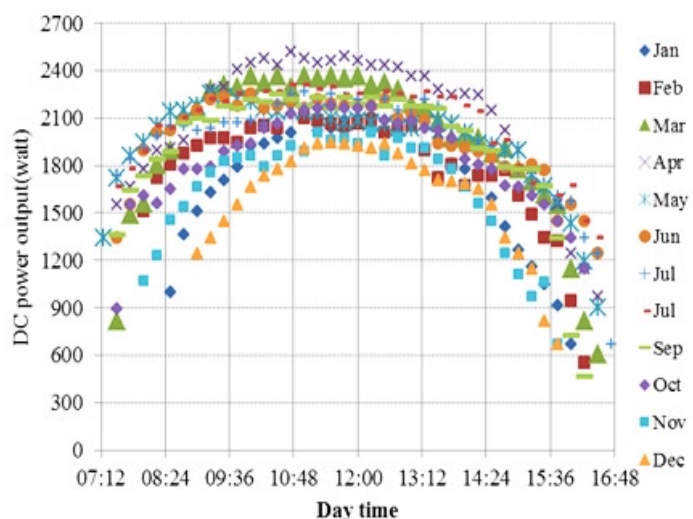

Fig. 2: The mean monthly diurnal variation in $D$. C. power output from $3.0 \mathrm{kWp}$ solar panels on cloud free at Patna $\left(25.65^{\circ} \mathrm{N}\right)$

generally the pumps have, then, the mechanical power required would be of $1500 / 0.7=2150 \mathrm{~W}$. Therefore, the pump size should be of 3 H.P.

Since, the solar irradiance varies with day time and does not meet the Standard Test Condition (STC). Therefore, to know the actual power output from a solar array over a day for different months or seasons, a $3 \mathrm{kWp}$ solar array was installed in Eastern region (Patna, $25.65^{\circ} \mathrm{N}$ ) with manual sun tracking mechanism. The DC power output was recorded on every bright sunshine day at the interval of 15 minutes for different months round the year. The monthly averaged value was plotted as Figure 2. It was observed that, between 9.00 A.M. to 2.30 P.M. (IST), the power rating of the array was ranged from $1.9-2.4 \mathrm{~kW}$ in almost all the months except the months of November to January. Therefore, 3 HP pump could be operated successfully nearly for 6 hours daily nearly at rated power $(2.2 \mathrm{~kW})$. Hence, for every horsepower (HP) the operating solar array size should be of $1000 \mathrm{Wp}$ for successful operation of solar pumps in Eastern India.

Further, a 3HP-three phase submersible pump with factory rated power of $2.2 \mathrm{~kW}$ was used to extract groundwater at Patna. The pump was put at $20 \mathrm{~m}$ below the ground level in view of ground water depth scenario of this region, where in general the water depth below ground level is ranging from $2-10 \mathrm{~m}$ with annual fluctuations of \pm 2 to $\pm 4 \mathrm{~m}$ in pre and post monsoon seasons ${ }^{11}$. However, in Patna the

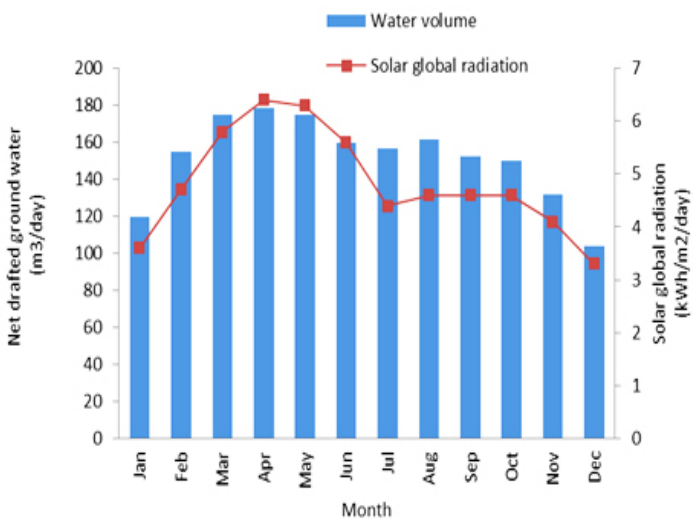

Fig.3: Mean monthly daily water output of submersible pump along with solar global radiation for different months

groundwater depth below ground level is ranging from 5 - $11 \mathrm{~m}$ with annual fluctuations of \pm 2 to $\pm 4 \mathrm{~m}$ in pre and post monsoon seasons. The pump was operated by $3036 \mathrm{Wp}$ solar array. The net drafted groundwater was recorded for every bright sunshine day round the year. The mean monthly daily water output for different months along with global solar radiation of corresponding months are shown in Figure 3. This figure illustrates that the mean monthly daily groundwater output was ranged from 150 - 175 $\mathrm{m}^{3}$ in the months of February to October, while in the months of November to January it was ranged from $100-120 \mathrm{~m}^{3}$. The difference in water output per day in different months could be attributed to change in ground water depth and value of global solar radiation.

\section{CONCLUSIONS}

The design, analysis and the results presented in this paper could be useful for designing of solar powered groundwater pumping systems as per the need and requirements of users in Eastern India

\section{ACKNOWLEDGEMENT}

Authors are thankful to the Indian Council of Agricultural Research, New Delhi for providing fund for designing and installation of solar powered groundwater pumping system for this study. 


\section{REFERENCES}

1. Lobell et.al. Prioritizing climate change adaptation needs for food security in 2030 Science, 319(5863), 607-610, (2008).

2. Held, I.M., Delworth T.L., Lu J., Findell K.L. and Knutson T.R., Simulation of Sahel drought in the 20th and 21st centuries. Proc Natl Acad. Sci., USA, 102: 17891-17896, (2005).

3. Lipton, M. Can Small Farmers Survive, Prosper, or be the Key Channel to cut Mass Poverty", Journal of Agricultural and Development Economics, 3(1): 58-85, (2006)

4. Polak P. and Yoder R. Creating wealth from groundwater for dollar-a-day farmers: Where the silent revolution and the four revolutions to end rural poverty meet. Hydrology J., 14: 424- 432 (2006)

5. World Development Report. Agriculture for Development, World Bank, Washington (2008)

6. Sharma, N.K., Tiwari P.K. and Sood Y.R. Solar energy in India: Strategies, policies, perspectives and future potential. Renewable and Sustainable Energy Reviews. 16: 933: 41, (2012)

7. Jaswal, A.K. Sunshine duration climatology and trends in association with other climatic factors over India for 1970: 2006, Mausam, 60: 43754 (2009)

8. Bhattacharya, S. C. and Jana C. Renewable energy in India: Historical developments and prospects. Energy, 34: 981; 91, (2009).

9. Hillel, D. Adaptation of modern irrigation methods to research priorities of developing countries. In: Le Moigne G, Barghouti S, Plusquellec $\mathrm{H}$ (eds) Technological and institutional innovation in irrigation. World Bank Technical Paper No. 94. World Bank, Washington, D.C., 88-93, (1989)

10. Keller, J., Adhikari D.L., Petersen M.R. and Suryawanshi S. Engineering low-cost micro-irrigation for small plots. In: Keller $\mathrm{K}$ (ed) The Kenya Case Study. Swiss Agency for Development and Cooperation, Berne. The decision to develop this paper evolved during a Fact Finding Study conducted in Kenya, India, and Nepal in March 2001. The Study was funded by the Swiss Agency for Development and Cooperation under a program championed by Dr. Urs Heierli, (2001)

11. Ground Water Year Book-India 2011-12. Central Ground Water Board, Ministry of Water Resources, Government of India, (2012). 